\title{
A new species and new distribution records of Pickeliana (Opiliones: Laniatores: Stygnidae)
}

\author{
Marcos R. Hara ${ }^{1} \&$ Ricardo Pinto-da-Rocha ${ }^{2}$ \\ ${ }^{1}$ Escola de Artes, Ciências e Humanidades, Universidade de São Paulo. Avenida Arlindo Bettio 1000, Ermelino Matarazzo, \\ 03828-000 São Paulo, São Paulo, Brasil. E-mail: marcosrh@usp.br \\ 2 Departamento de Zoologia, Instituto de Biociências, Universidade de São Paulo. Caixa Postal $1146105422-970$ São \\ Paulo, São Paulo, Brasil. E-mail: ricrocha@usp.br
}

\begin{abstract}
A new species of Pickeliana Mello-Leitão, 1932, P. albimaculata sp. nov., is described from Jussari, Bahia, Brazil. It can be easily distinguished from the already described species by the presence of white spots on mesotergal area I and anal opercle. It is similar to P. pickeli Mello-Leitão, 1932 by the presence of a large, ventroapical pointed tubercle on femora III-IV. A cladistic analysis was performed adding a new character to the available character matrix, the presence of a large and ventro-apical pointed tubercle on male femur IV. According to this analysis, P. albimaculata sp. nov. is sister species of P. pickeli. Additionally, we present an identification key and an update on the geographical distribution of species of this genus in northeastern Brazil.
\end{abstract}

KEY WORDS. Brazilian fauna; Neotropics; systematics; Stygninae; taxonomy.

RESUMO. Uma nova espécie e novos registros de distribuição para Pickeliana (Opiliones:Laniatores: Stygnidae). Uma nova espécie de Pickeliana Mello-Leitão, 1932, P. albimaculata sp. nov., é descrita oriunda de Jussari, Bahia, Brasil. A nova espécie pode ser distinguida das demais pela presença de manchas brancas na área I e no opérculo anal. Assemelha-se a P. pickeli Mello-Leitão, 1932 devido à presença de tubérculos ventroapicais grandes no fêmur III e IV. Uma análise cladística foi realizada adicionando um novo caráter à matriz disponível, a presença de tubérculo ventro-apical grande, acuminado no fêmur IV do macho. De acordo com essa análise, $P$. albimaculata sp. nov. é espécie-irmã de $P$. pickeli. Novos registros de distribuição geográfica na região Nordeste do Brasil e uma chave de determinação das espécies do gênero são apresentados.

PALAVRAS-CHAVE. Fauna brasileira; Neotrópico; sistemática; Stygninae; taxonomia.

Ten years have passed since the systematic review of Stygnidae (PINTO-DA-RochA 1997) was published. The article is a landmark in the study of Neotropical harvestmen because it reviewed the whole family and proposed relationships among species using a cladistic analysis for the first time. Besides that article, only few others presented cladistic analysis for Neotropical harvestmen: KurY (1994), PINTO-DA-Rocha (2002) and PINTODA-Rocha \& Kury (2003). During the past ten years, many surveys have been conducted in northern South America and nearby areas, resulting in the discovery of many new species of stygnids among freshly collected specimens. Those species were described by several authors, such as Osvaldo Villarreal-Manzanilla, Ricardo Pinto-da-Rocha, Adriano B. Kury and collaborators: Stygnidius yekwana (VILlarREAL-ManzanilLa 2004), Stenophareus aonda and S. guerreroi (VillarReAL-MANZANilla et al. 2007), seven new species of Protimesius Roewer, 1913 (Pinto-Da-Rocha 2000, VillarrealManzanilla \& Pinto-da-Rocha 2006, Kury \& Pinto-Da-Rocha 2008), Stygnoplus lomion (Villarreal-Manzanilla \& Rodríguez 2004), and Phareus antrophilus (Villarreal-Manzanilla \& Rodrigues 2006). To date, Stygnidae comprises 86 species occurring from northeastern to northwestern Brazil, Peruvian, Colombian and Venezuelan Amazonia, French Guyana, and Surinam.

Pickeliana Mello-Leitão, 1932, is one of the less diverse genera of the family. It was proposed by Mello-Leitão (1932) when he described $P$. pickeli Mello-Leitão, 1932. Three years later, the same author synonymized Pickeliana under Ideostygnus Sørensen, 1932 (Mello-Leitão 1935). Later, SoAREs \& SoARes (1978) revalidated Ideostygnus and removed Pickeliana from its synonymy. However, in the same year, SoARes (1978) synonymized Pickeliana under Protimesius Roewer, 1913. Finally, after a systematic review using cladistic analysis (PINTO-DA-RochA 1997), Pickeliana capito (Soares \& Soares, 1974) was included in the genus, and the monophyly of the genus was supported by five synapomorphies.

In this paper, we describe a new species of Pickeliana (Stygninae), a genus diagnosed by the following characters (PINTO-DA-Rocha 1997): rectangular dorsal scutum; smooth anterior margin; male ocularium tuberculate; divided area I; area

Revista Brasileira de Zoologia 25 (3): 515-522, September, 2008 
III with a pair of spines; free tergites with similar-sized tubercles; pedipalpal femur and patella elongated, longer than dorsal scutum; reduced tarsal process, and the bifid basal setae on ventral plate of the penis. According to PINTO-DA-RochA (1997), a very long pedipalpal patella and presence of scopula on the tarsi support Protimesius as sister group of Pickeliana. The already described Pickeliana species are known from few localities: $P$. capito occurs in six different localities of two municipalities in the state of Bahia and $P$. pickeli, in three localities of two municipalities in the state of Pernambuco. In this study we propose a relationship hypothesis for all the species of the genus; we provide an identification key and update the knowledge on their geographical distribution.

\section{MATERIAL \& METHODS}

Most methods follow PINTO-DA-Rocha (1997). Coloration is based on fixed specimens in 70\% ethylic alcohol. Abbreviations are as follows: (CHL II) cheliceral segment II, (CHL III) cheliceral segment III, (DSL) dorsal scutum length, (DSW) dorsal scutum width, (ID) interocular distance, (fe) female, (FM) femur, (ma) male, (MT) metatarsus, (PL) prosoma length, (PT) patella, (PW) prosoma width, (TA) tarsus, (TI) tibia, (TR) trochanter. Acronyms of repositories are IBSP (Instituto Butantan, São Paulo) and MZSP (Museu de Zoologia, USP, São Paulo). Pedipalpal tibia and tarsus setae coding follows previous authors (PINTO-DA-Rocha 1997) i.e. " $\mathrm{i}$ " means small setae (half the size of the longest setae), "I" means long setae and are mentioned from basal to distal order. All appendage measurements refer to the right side and are in millimeters. Only features contrasting the male were considered in the female description. Differences in number of tubercles on dorsal scutum and of smaller tubercles on legs were not considered in the descriptions of the female and male intraspecific variation.

The data matrix used in the cladistic analysis was based on PINTO-DA-Rocha (1997). As in the original analysis, we kept multistate characters 18, 20 and 50 ordered. The scopula (character 30 of PINTO-DA-RochA 1997) is here reinterpreted as absent in Pickeliana. The added new character was:

51 - large, ventro-apical pointed tubercle on femur IV (CI 0.50, RI 0.75, L 2): 0, absent; 1, present.

We included all genera of Stygninae as outgroups since we were mainly concerned with the relationship among species of Pickeliana. The following taxa were used: Phareus raptator (Gervais 1844); Auranus hoeferscovitorum Pinto-da-Rocha, 1997; Stygnus multispinosus (Piza, 1938); Sickesia helmuti H. Soares, 1979; Verrucastygnus caliginosus (Pinto-da-Rocha, 1990); Stenostygnoides cosmetitarsus Roewer, 1913; Protimesius evelineae (Soares \& Soares, 1978); P. laevis (Sørensen, 1932). We also included Nomoclastes quasimodo Pinto-da-Rocha, 1997 (Nomoclastinae) in the analysis to root the tree. The matrix was edited in computer software NDE 0.5.0 (PAGE 2001), and cladistic analysis was performed in computer software Nona vers. 2.0 (Goloboff 1998) using Winclada interface (NixON 2002).
We performed three series of 1000 replications of tree constructions using random addition sequences of taxa, and submitting the most parsimonious trees to a branch swapping process by TBR ("Tree Bisection and Reconnection branch swapping", SWOFFORD 1991) using the command mult*1000, retaining the 100 most parsimonious trees by replication until reaching a maximum of 1000 trees (using command "hold 1000; hold/100); and submitting the shortest trees to another sequence of TBR (using "mult*max*). To preserve our hypothesis of primary homology, we chose ACCTRAN optimization (Depinna 1991).

To discuss the distribution of Pickeliana, we used the following additional material: Pickeliana capito: BrazIL, Bahia: Itabuna (campus CEPLAC), 1 fe (IBSP 1120); Itamarajú (Parque Nacional Monte Pascoal), 5 fe (IBSP 225, 1881, 1883, 1884); idem, 1 fe (MZSP 26946); Jussari (Reserva Natural da Serra do Teimoso), 3 fe (IBSP 1159); Prado (Parque Nacional Descobrimento), 1 ma (MZSP 26947); Porto Seguro (Estação Ecológica Pau Brasil), 3 ma \& 7 fe (IBSP 1000, 1002, 1004, 1008, 1017, 1019, 1020, 1025, 1027); Salvador (Parque Municipal do Pituaçú), 2 fe (IBSP 28857, 28858); Una (Reserva Biológica de Una), 4 ma \& 20 fe (IBSP 1043, 1045, 1066, 1148, 1616, 1617, 1665, 2304, 2316). Pickeliana pickeli: BraziL, Alagoas: Maceió, 2 fe (IBSP 3904); Murici (Estação Ecológica de Murici), 2 ma \& 2 fe (IBSP 7019, 7026, 7052, 7068); São Miguel, 1 ma (MZSP 18919); Usina Serra Grande, 2 fe (IBSP 7548). Paraíba: João Pessoa (Mata do Buraquinho), 12 ma \& 31 fe (IBSP 7298, 7300, 7302, 7306, 7307, 7309, 7311, 7316, 7318, 7329, 7332, 73337336, 7343, 7354, 7363-7365, 7369-7371, 7383, 7386). Sergipe: Itabaiana (Estação Ecológica Itabaiana), 8 ma \& 8 fe (IBSP 1374, 1378, 1385, 1741, 1745); Santa Luzia do Itanhy (Mata do Castro), 2 fe (IBSP 3904). Pernambuco: Recife (Horto Dois Irmãos), 3 ma \& 11 fe (IBSP 694, 1364, 1391 1392, 1846).

The following locations were extensively surveyed using standardized methods of collection during five days, according to protocols of the project Biodiversity of Arachnida and Myriapoda of the State of São Paulo (IBSP, MZSP) (PINTO-DARocha et al. 2005): Bahia: Itamarajú, Jussari, Porto Seguro, Salvador, Una; Alagoas: Murici; Sergipe: Itabaiana, Santa Luzia do Itanhy; Pernambuco: Recife.

\section{RESULTS}

\section{Key to the species of Pickeliana}

1. Dorsal scutum with white spots on mesotergal area I and anal operculum $P$. albimaculata new species

$1^{\prime}$. White spots absent

2. Anal operculum with two median tubercles; male femur IV ventrally with two rows of tubercles, prolateral row with larger tubercles in distal half, retrolateral row with larger tubercles on distal quarter; two ventro-apical larger pointed tubercles; pedipalpal tibia concolor with other segments(Fig. 12) .................................................................... P. pickeli 
2 '. Anal operculum with three median tubercles and two on posterior margin; male femur IV only with small tubercles on basal region; ventro-apically unarmed; pedipalpal tibia yellowish, contrasting with remaining segments (Fig. 11).... P. capito

\section{Pickeliana albimaculata sp. nov.}

\section{Figs 1-10}

Type material.BraziL, Bahia: Itororó (Serra do Oricana), III.2000, G. Machado, 1 male holotype (MZSP 19349); Jussari (Reserva Natural da Serra do Teimoso), 1 male and 1 female paratypes (IBSP 990).

Etymology. The epithet comes from Latin words, "albus" = white, and "maculatus" = spotted, in reference to the color on the mesotergal area I and anal operculum.

Diagnosis. It can be easily distinguished from other species of Pickeliana by the presence of white spots on mesotergal area I and anal opercle. $P$. albimaculata is more similar to $P$. pickeli due to the ventro-apical large and pointed tubercles on femora III-IV.

Male holotype (MZSP 19349). Measurements: DSL 2.6, DSW 2.3, CL 1.1, CW 2.2, ID 1.6, CHL II 2.6, CHL III 0.9, see table I for appendages measurements. Dorsum (Fig 1 and 2): prosoma smooth. Ocularium tuberculate. Area I divided, with a white spot on each side and 1-2 tubercles; II smooth; III with two tubercles behind the pair of parallel spines. Lateral margin with a row of tubercles from coxa III to posterior margin. Posterior margin of dorsal scutum and free tergites I-III respectively with 7, 7, 6, 7 tubercles. Anal opercle with white spot, one paramedian pair of larger tubercles, four on posterior margin. Venter: coxa I with two sparse tubercles, median row of 7-9, posterior row of 3-4 tubercles; II-IV with sparse tubercles, II with 2-3 apical larger tubercles. Posterior margin and free sternites with a row of low tubercles. Chelicera: Swollen. Bulla with four tubercles; II with four small distal teeth; III with one wide basal, one wide median, 4-5 distal small teeth. With interchelar space. Pedipalpus (Fig. 3): Slightly elongated. Coxa dorsally with one mesal, 1-2 ectal tubercles; ventrally with three tubercles. Trochanter inflated, with one ventral tubercle. Femur with one ventro-basal small tubercle. Patella smooth, swollen apicad. Tibia: ectal IIIIi/ IIIII, mesal IIIIi. Tarsus: ectal iIili, mesal IIIIi. Legs (Figs 4 and 5): coxa I-II with one anterior and one pos- terior tubercles; II with posterior largely fused with anterior of III; III with one posterior which is fused apically with anterior of IV; IV with scattered tubercles, one large, pointed dorso-apical tubercle. Trochanters I-IV with sparse tubercles; I-III ventrally with four larger, basal largest; II with one dorsal larger; III with two dorsal larger, one apical-retrolateral larger; IV with two dorsal larger, one apical retrolateral larger, 4-5 ventral larger tubercles. Femora I-IV with minute tubercles roughly organized in six rows (two dorsal, one prolateral, one retrolateral and two ventral), one pair of dorso-apical tubercles of similar size; III with ventroprolateral row of larger tubercles increasing in size subapicad; IV with larger tubercles in most of ventro-prolateral row, only subapicad in ventro-retrolateral row, on basal region in retrolateral row, only two in prolateral row, two ventro-apical larger pointed tubercles. Patellae I-II unarmed; III with a dorso-retrolateral larger tubercle; IV with a pair of dorso-apical larger tubercles of similar size. Tibiae I-IV unarmed. Metatarsi I-II unarmed; III-IV with a pair of ventro-apical setae. Tarsal segmentation: 7(3), 13(3), 6, 7. Penis (Figs 9 and 10): Ventral plate thick, distal margin straight, lateral margins concave; with three pairs of apical setae larger than ventral plate width, three pairs of bifid basal setae, without small intermediary setae. Glans with dorsal process; without ventral process. Coloration: Brown. Ocularium, mesotergal area III spines, free tergites, distal patellae and tibiae I-IV dark brown. Chelicerae, pedipalps and distal metatarsi and tarsi light brown. White spots on area I and anal opercle.

Female paratype (IBSP 990) (Figs 6-8). Measurements: DSL 2.8, DSW 2.3, CL 1.1, CW 2.0, ID 1.5, CHL II 1.3, CHL III 0.6, see table I for appendage measurements. Ocularium smooth. Area III with one pair of slightly divergent spines. Chelicera: not swollen; segment III with 4-6 tubercles, basal larger and inconspicuous. Without interchelar space. Pedipalpus: tibia ectal IIiIi. Legs: coxa IV with one dorso-apical larger tubercle (smaller than male). Trochanter IV with one dorsal larger, one apical retrolateral larger tubercle. Femur IV with rows of tiny tubercles of similar size. Patellae III unarmed; IV with a pair of dorso-apical tubercles. Tarsal segmentation: 7-8(3), 15(3), 6, 7.

Male variation $(\mathrm{n}=2)$. DSW 2.2-2.3; PW 2.0-2.2; ID 1.61.7; CH II 2.6-2.8; CH III 0.9-1.0. Pedipalp tibia spination: mesal IIIIi, IIIII, ectal IIiIIi, IIIIi, IIIII. Tarsal segmentation 7-8(3); 15$16(3) ; 6 ; 7$.

Table I. Pickeliana albimaculata sp. nov., measurements of appendages of male holotype (underlined), paratype and female paratype (in brackets). * Podomer of the left side.

\begin{tabular}{|c|c|c|c|c|c|c|c|}
\hline Appendages & TR & $\mathrm{FE}$ & PT & $\mathrm{TI}$ & MT & TA & Total \\
\hline I & $\underline{0.5}-0.5(0.4)$ & $\underline{2.5}-2.8(2.5)$ & $\underline{0.7-0.8 \quad(0.7)}$ & $\underline{1.9}-2.0(1.9)$ & $\underline{3.0}-3.3(3.0)$ & $1.3-1.4(1.4)$ & 9.9-10.8 \\
\hline II & $\underline{0.6}-0.6(0.6)$ & $\underline{5.2-5.7(5.2)}$ & $\underline{1.0}-1.0(1.0)$ & $\underline{3.7-4.1(3.7)}$ & $\underline{5.2-5.8(4.6)}$ & $\underline{3.5}-4.1\left(3.8^{*}\right)$ & $19.2-21.3(18.9)$ \\
\hline III & $\underline{0.7-0.7(0.6)}$ & 3.4-3.9 (3.7) & $\underline{1.0}-1.0(1.0)$ & $\underline{2.1}-2.2(2.1)$ & $\underline{3.7-4.3(3.8)}$ & $\underline{2.1}-2.2(2.0)$ & $\underline{12.1}-13.2(13.2)$ \\
\hline IV & $\underline{0.7}-0.8(0.7)$ & $\underline{5.3}-5.7(5.3)$ & $\underline{1.1-1.2(1.1)}$ & $\underline{2.8}-2.9(2.8)$ & $\underline{6.0}-6.8(5.9)$ & $\underline{2.8}-2.8(2.6)$ & $\underline{18.7}-20.2(18.4)$ \\
\hline Pedipalp & $\underline{0.4}-0.6(0.5)$ & $\underline{2.6}-2.8(2.7)$ & $1.9-2.0$ (1.9) & $1.0-1.1(1.1)$ & - & $\underline{0.9}-0.9(1.0)$ & $\underline{6.7-7.4}$ \\
\hline
\end{tabular}



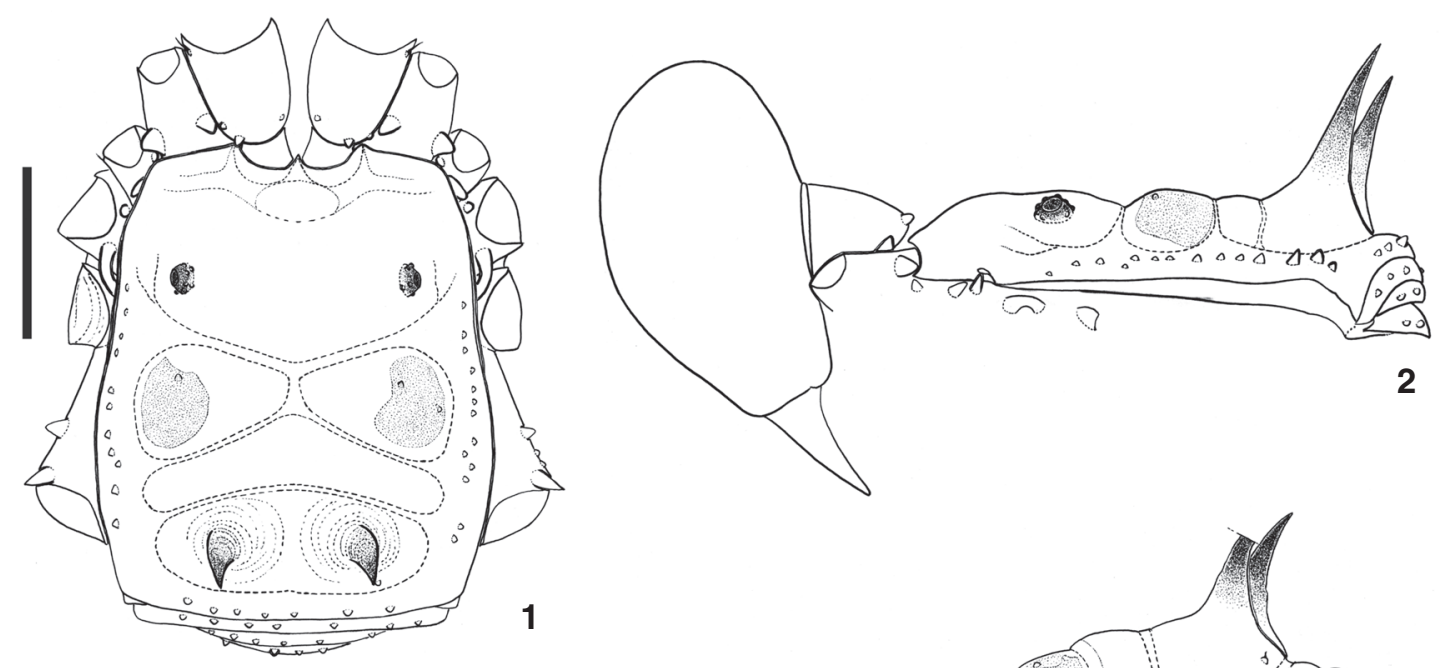

1
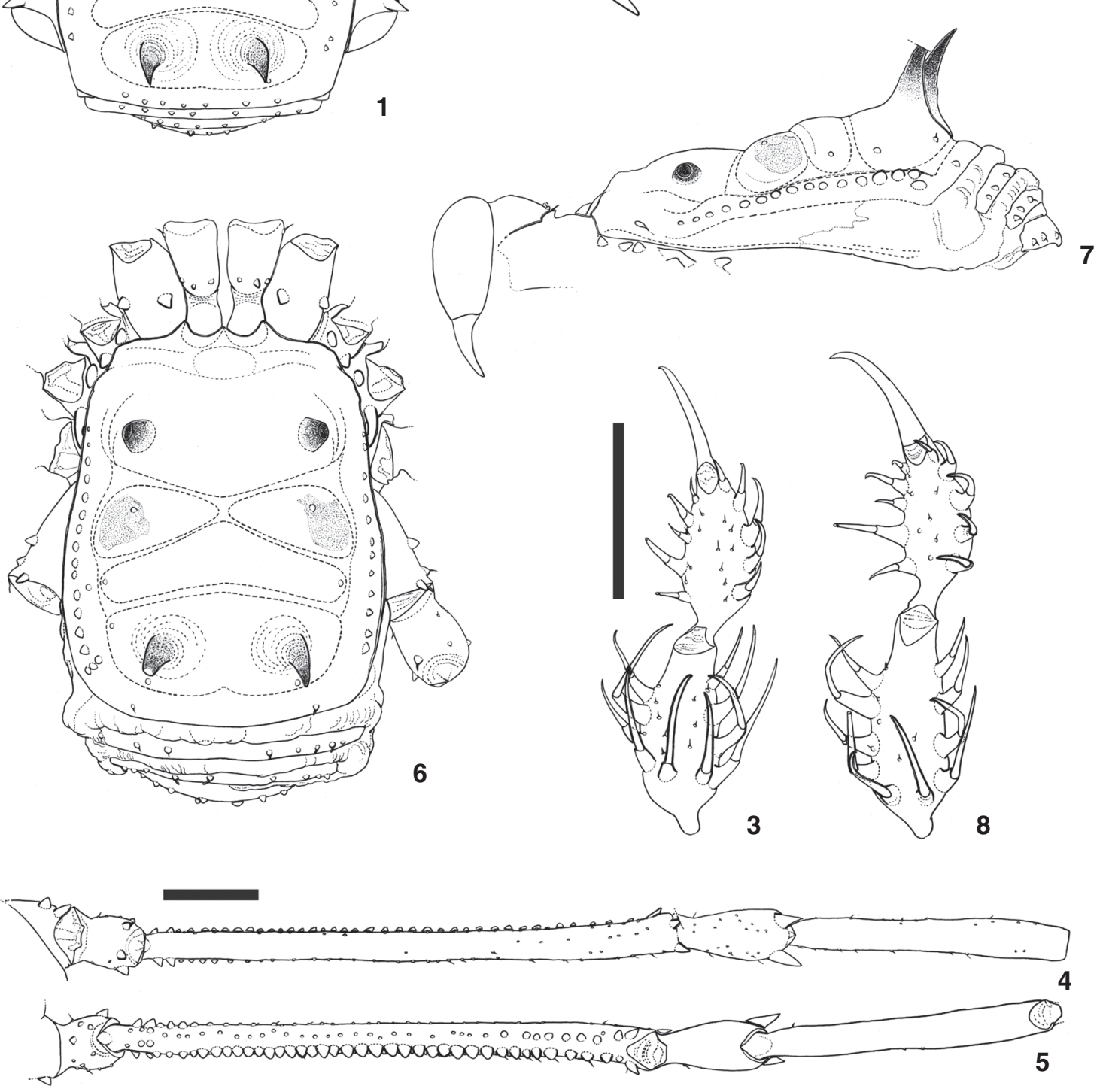

Figures 1-8. Pickeliana albimaculata sp. nov. (1-2) Male holotype, habitus: (1) dorsal view; (2) right lateral view;(3) male holotype, right pedipalpal tibia and tarsus, ventral view; (4-5) male holotype, right leg IV: (4) dorsal view; (5) ventral view; (6-8) female paratype, habitus: (6) dorsal view; (7) right lateral view; (8) female paratype, right pedipalpal tibia and tarsus, ventral view. Grey spots in area I mean white spot. Scale $=1 \mathrm{~mm}$. Figures in the same scale: 1, 2, 6 and 7; 3 and 8; 4 and 5 . 

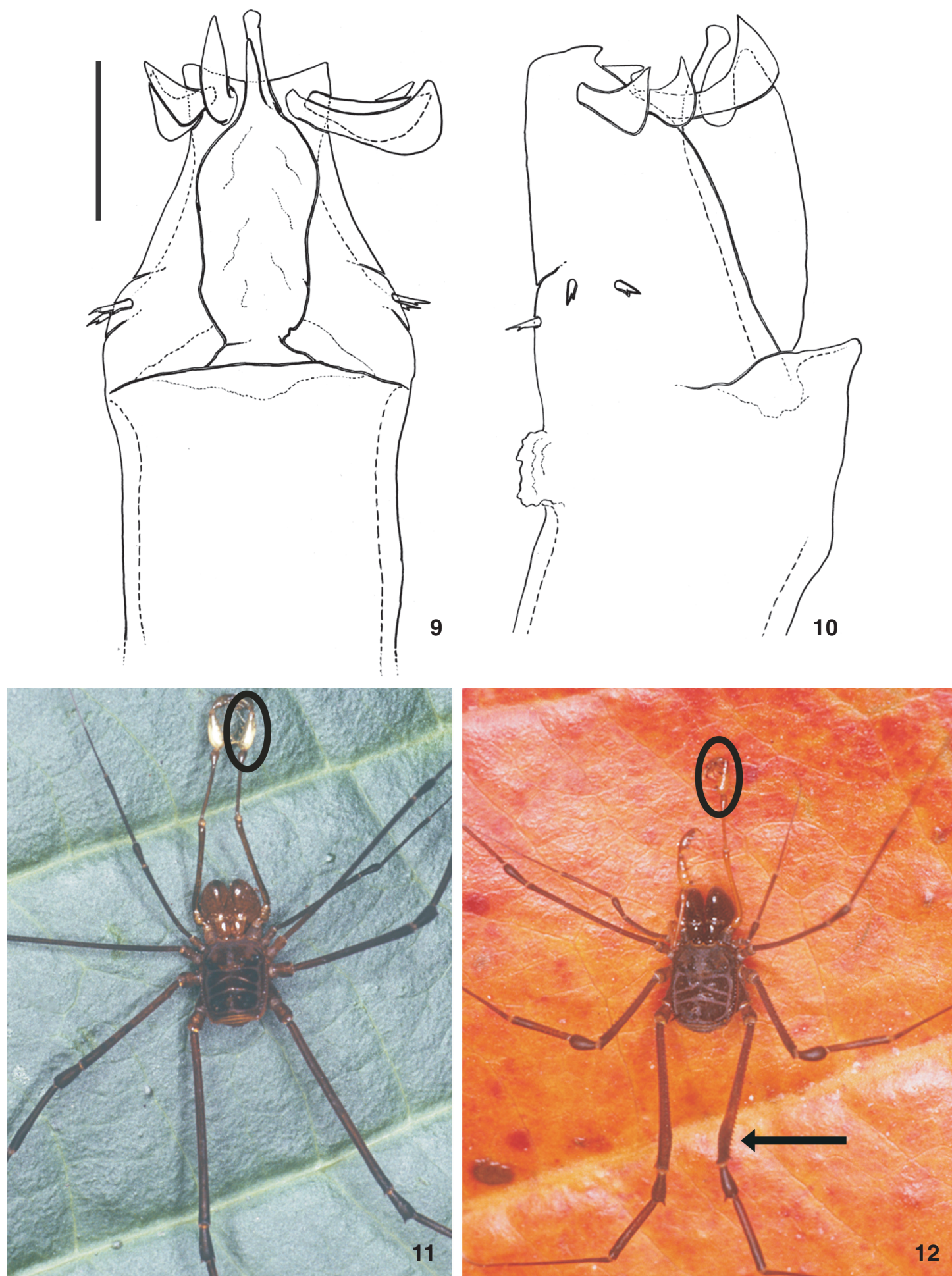

Figures 9-12. (9-10) Pickeliana albimaculata sp. nov., holotype, penis: (9) dorsal view; (10) right lateral view. Scale = $1 \mathrm{~mm}$. (11-12) Males: (11) Pickeliana capito, Campus CEPLAC, Itabuna, Bahia; (12) P. pickeli, Horto Dois Irmãos, Recife, Pernambuco. The empty circles indicate the difference in the pedipalpal tibia coloration, a diagnostic feature. The setae indicate the row of prolateral row with larger tubercles in distal half on femur IV. 
Cladistic analysis. Pickeliana albimaculata was included in the matrix published by PINTO-DA-Rocha (1997) and shares the same states as $P$. pickeli except for the following characters (state of $P$. albimaculata in parentheses): 10(1); 23(0); 47(-). Presence of ventro-apical large, pointed tubercle on femur IV occurs in Phareus raptator, Pickeliana pickeli, P. albimaculata, Stygnus multispinosus and Sickesia helmuti, being absent in the remaining taxa.

Cladistic analysis resulted in a single most parsimonious tree (CI 0.65; RI 0.66; L 66). Characters 2-3, 6-12, 14-17, 19, 22, $24,27-29,31-35,38-40,43,45$ and 48 were considered uninformative. The same topology of PINTO-DA-RochA (1997) was observed for the subfamily Stygninae: (Nomoclastes quasimodo (Phareus raptator (Stygnus multispinosus, Sickesia helmuti)) (Auranus hoeferscovitorum (Verrucastygnus caliginosus (Stenostygnoides cosmetitarsus ((Protimesius evelineae, P. laevis) (Pickeliana capito (P. pickeli, P. albimaculata)))))))). Although character 30 was reinterpreted as absent in Pickeliana, it has not affected the monophyly of Pickeliana, which is supported by five unambiguous synapomorphies: male ocularium tuberculated (homoplasy with $P$. raptator and $S$. helmuti); straight apex of pedipalpal tibial anterior sockets (reversion); wide and compressed distal setae of ventral plate (homoplasy with $S$. multispinosus); bifid basal setae of ventral plate; 2-3 pairs of truncus setae (homoplasy with $N$. quasimodo, S. multispinosus and S. helmuti). Pickeliana albimaculata has an autapomorphy (10[1], white spots on dorsal areas) and shares with $P$. pickeli, which is its sister-species, the presence of a large, ventro-apical, pointed tubercle on femur IV (homoplastically present in $P$. raptator, $S$. multispinosus and $S$. helmuti).

\section{DISCUSSION}

Distribution. Pickeliana capito and P. pickeliana were previously known only from type-localities and very close sites. However, examination of 130 specimens, accumulated in the last ten years in Brazilian museums, allowed for a more precise assessment of the geographical distribution of these species (Fig. 13). The records indicate that Pickeliana is restricted to the Northern coast of Brazil, from which moving inland there is a semidesertic region, characterized by low rainfall, restricted to few months of the year. However, we stress that such distribution should be taken with care, because surveys in that region of the country are restricted to areas located less than $150 \mathrm{~km}$ from the coast and because there are gaps, such as those between Santa Luzia do Itanhy and Salvador and Salvador and Itajibá. These issues might hamper a more accurate analysis of their geographical distribution, but considering that harvestmen usually have high levels of endemism and that most of them are restricted to humid forested areas (PINTO-DA-RochA et al. 2005, 2007), the data at hand enables us to make a more realistic discussion. In addition to the new localities for Pickeliana, three localities (Maranhão: Barreirinhas; Paraíba: Areia; Bahia: Ilhéus), placed more to the north, were sampled using the same methodology

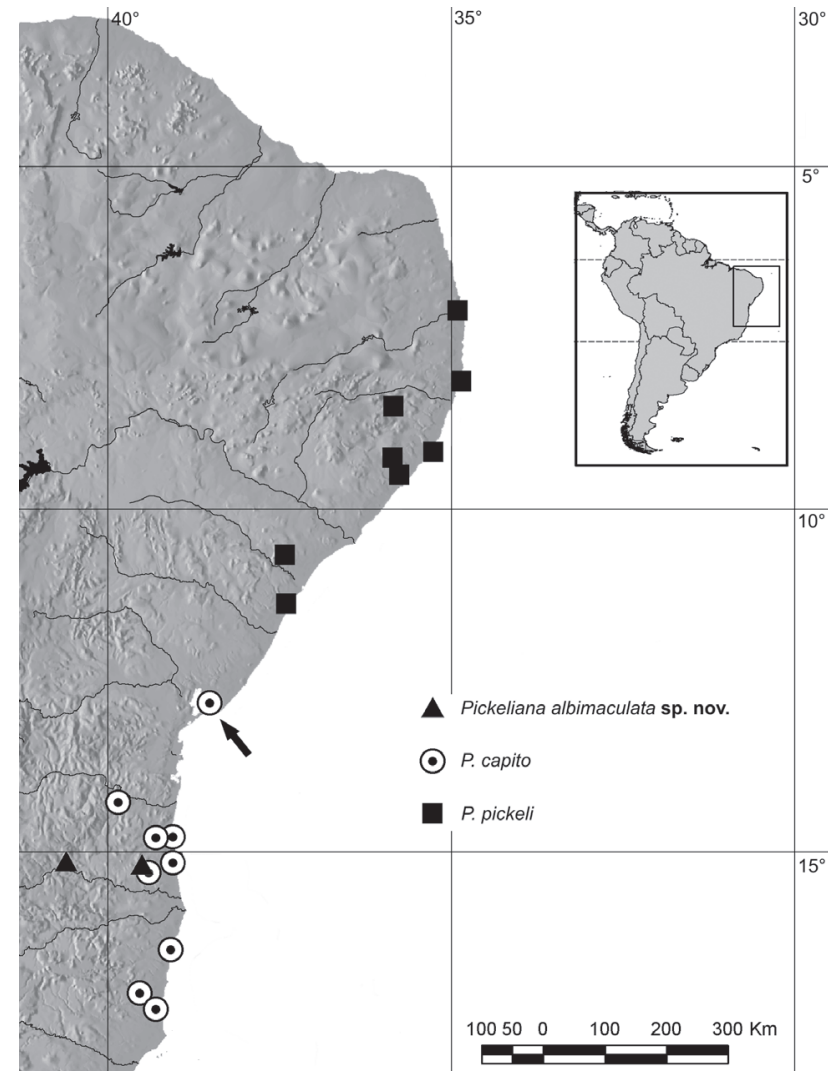

Figure 13. Records of distribution of species of Pickeliana. Arrow indicates the Baía de Todos os Santos.

but no specimen of Pickeliana was collected. Thus, the Northern limit of their distribution could be here more clearly defined. As mentioned above, the limit of the distribution of the genus and also of the abundant rainfall is the slope of the northeastern Atlantic shield (Borborema plateau and São Francisco craton). All examined species of Pickeliana were restricted to coastal lowlands and close mountain chains: P. albimaculatus $(220-350 \mathrm{~m}$ a.s.1.); P.capito (20-170 m); and P.pickeli (20-380 m). Pickeliana pickeli was only collected north of the Baía de Todos os Santos (Paraíba, Pernambuco, Alagoas and Sergipe States) while $P$. albimaculata and $P$. capito occur in partial sympatry in southern Bahia (between Jequitinhonha and das Contas rivers). The disjunctive distribution of biota in Bahia has been explained by a previous biogeographical hypothesis based on phylogenetic reconstruction for Neotropical diversification (Müller 1973, Prance 1982, Amorim \& Pires 1996, Bates et al. 1998, Amorim 2001, Silva et al. 2004, Pellegrino et al. 2005). According to that hypothesis based on phylogenetic reconstruction for vertebrates, angiosperms and dipterans, a major division between areas of endemism in Coastal Northeastern Brazil occurred in the Baía de Todos os Santos region (Paraguaçu River valley), separating the previous biota found in southern Bahia from the rest of north-

Revista Brasileira de Zoologia 25 (3): 515-522, September, 2008 
eastern Brazil. However, P. capito also occurs in the Baía de Todos os Santos, and therefore, a more thorough survey is needed between Santa Luzia do Itanhy and Salvador to better define the limits between $P$. capito and $P$. pickeli and to understand their distribution. Besides, the only available hypothesis of biogeographical relationships for Brazilian opilionids covers only the southern distribution of Pickeliana in south Bahia, an area closely related to southern and southeastern costal mountain ranges (PINTO-DA-Rocha et al. 2005) and a new hypothesis covering all Atlantic Rain Forest (Northeastern Brazil coast) opilionid distribution is necessary.

\section{ACKNOWLEDGEMENTS}

We thank Antonio D. Brescovit, for the loan of material from Instituto Butantan, for Marcio B. da Silva and Adalberto Santos, for valuable comments on localities and geographical distribution patterns. Cristina Rheims kindly reviewed the language.

\section{LITERATURE CITED}

Amorim, D.S. 2001. Dos Amazonas, p. 245-255. In: J. Llorente \& J.J. Morrone (Eds). Introducción a la Biogeografia en Latinoamérica: teorías, conceptos, métodos y aplicaciones. (México, Las Prensas de Ciencias, 277p.

Amorim, D.S. \& M.R.S. Pires. 1996. Neotropical biogeography and a method for a maximum biodiversity estimation, $p$. 183-219. In: C.E.M. Bicudo \& N.A. Menezes (Eds). Biodiversity in Brazil. A first approach. São Paulo, Conselho Nacional de Desenvolvimento Científico e Tecnológico, 326p.

Bates, J.M.; HaCketT; S.J. \& J. CRACRAFt. 1998. Area-relationships in the Neotropical lowlands: an hyphothesis based on raw distributions of Passerine birds. Journal of Biogeography 25: 783-793.

Depinna, M.C.C. 1991. Concepts and tests of homology in the cladistic paradigm. Cladistics 7: 367-394.

Goloвоf, P.A. 1998. NONA, vers. 2.0. Software available online at: http://www.cladistics.com [Accessed in 01.XII.2004].

KurY, A.B. 1994. Early lineages of Gonyleptidae (Arachnida Opiliones Laniatores). Tropical Zoology 7:343-353.

Kury, A.B. \& R. PInTo-Da-Rocha. 2008. First record of Stygnidae for the State of Espírito Santo and description of a new Protimesius (Arachnida: Opiliones: Laniatores). Revista Brasileira de Zoologia 25 (2): 319-322.

Mello-Leitão, C.F.1932. Opiliões do Brasil. Revista do Museu paulista 17 (Parte 2): 1-505.

Mello-Leitão, C.F. 1935. Algumas notas sobre os Laniatores. Arquivos do Museu Nacional do Rio de Janeiro 36: 89-116.

MÜLLER, P. 1973. The dispersal centers of terrestrial vertebrates in the Neotropical realm. The Hague, W. Junk B.V. Publishers, 244p.

Nixon, K.C. 2002. Winclada, version 1.00.08. Software available online at: http://www.cladistics.com [Accessed in 01.XII.2004].
Page, R.D.M. 2001. Nexus Data Editor, vers. 0.5.0. Software available online at: http://taxonomy.zoology.gla.ac.uk/rod/ NDE/nde.html [Accessed in 01.XII.2004].

Pellegrino, K.C.M.; M.T. Rodrigues; A.N. Waite; M. Morando; Y.Y. YASSUDA \& J.W. Sites JR. 2005. Phylogeography and species limits in the Gymnodactylus darwinii complex (Gekkonidae, Squamata): genetic structure coincides with river systems in the Brazilian Atlantic Forest. Biological Journal of the Linnean Society 85: 13-26.

PINTO-DA-RochA, R. 1997. Systematic review of the Neotropical family Stygnidae (Opiliones, Laniatores, Gonyleptoidea). Arquivos de Zoologia 33 (4): 163-342.

PINTO-DA-Rocha, R. 2000. A new species of Protimesius from Brazil (Opiliones: Stygnidae). Aracnologia 28: 1-4.

PINTO-DA-Rocha, R. 2002. Systematic review and cladistic analysis of the Brazilian subfamily Caelopyginae (Opiliones: Gonyleptidae). Arquivos de Zoologia 36 (4): 357-464.

PinTo-DA-Rocha, R. \& A.B. Kury. 2003. Phylogenetic analysis of Santinezia with description of five new species (Opiliones, Laniatores, Cranaidae). Journal of Arachnology 31 (2): 173208.

Pinto-DA-Rocha, R.; M.B. da Silva \& C. Bragagnolo. 2005. Faunistic similarity and historic biogeography of the harvestmen of southern and southeastern Atlantic Rain Forest of Brazil. Journal of Arachnology 33: 290-299.

Pinto-da-Rocha, R.; G. Machado \& G. Giribet. 2007. Harvestmen the biology of Opiliones. Harvard Harvard University Press, $597 \mathrm{p}$.

Prance, G. T. 1982. Forest refuges: evidence from woody angiosperms, p. 137-158. In: G. T. Prance (Ed.). Biological diversification in the tropics. New York, Columbia University Press, XVI+714 p.

Silva, J.M.C.; M.C. Sousa \& C.H.M. Castelletti. 2004. Areas of endemism for passerine birds in the Atlantic forest, South America. Global Ecology and Biogeography 13: 85-92.

SOARES, B.A.M. \& H.E.M. SOARES. 1974. Opera opiliologica varia. IV. (Opiliones, Gonyleptidae, Stygnidae). Revista brasileira de Biologia 30 (3): 339-350.

SoARes, H.E.M. 1978. Opera opiliologica varia. XI. Misetropius mendopticus, novo gênero e nova espécie e notas sinonímicas de Stygnidae. Revista brasileira de Entomologia 22 (2): $71-76$.

SOARES, H.E.M. \& B.A.M. SOARES. 1978. Opera opiliologica varia V. (Opiliones, Stygnidae). Boletim Zoológico, Universidade de São Paulo 3: 81-96.

Swofford, D.L. 1991. PAUP* Phylogenetic Analysis Using Parsimony, version 3.1. Campaign, software and manual, Illinois Natural History Survey.

Villarreal-Manzanilla, O. 2004. Descripcíon de una nueva especie del género Stygnidius (Opiliones, Stygnidae) del Cerro Marahuaca, en el Amazonas venezolano. Revista Ibérica de Aracnologia 9: 15-18.

Villarreal-Manzanilla, O. \& R. Pinto-da-Rocha. 2006. Five new 
species of Protimesius from Brazil (Opiliones: Stygnidae). Zootaxa 1325: 219-233.

Villarreal-Manzanilla, O.\& C. Rodríguez. 2004. Descripción de una nueva especie y dos nuevos registros del género Stygnoplus (Opiliones, Stygnidae) para Venezuela. Revista Ibérica de Aracnología 10: 179-184.

Villarreal-Manzanilla, O. \& C. Rodríguez. 2006. Nuevos registros del género Phareus Simon, 879 en Colombia con la descripcíon de una nueva especie (Opiliones, Stygnidae). Boletín de la SEA 38: 103-105.

Villarreal-Manzanilla, O.; C. Donascimiento \& C.J. Rodríguez. 2007. Two new species of Stenophareus (Opiliones: Laniatores: Stygnidae) from the Venezuelan Guiana Shield. Zootaxa 1471: 43-51.

Submitted: 21.III.2008; Accepted: 03.IX.2008.

Editorial responsibility: Antonio D. Brescovit 